\title{
Area Monitoring Dosimeter Program for the Pacific Northwest National Laboratory: Results for CY 1998
}

S.R. Bivins

G.A. Stoetzel

June 1999

Prepared for

the U.S. Department of Energy

under Contract DE-AC06-76RLO 1830

Pacific Northwest National Laboratory

Richland, Washington 99352 


\section{DISCLAIMER}

This report was prepared as an account of work sponsored by an agency of the United States Government. Neither the United States Government nor any agency thereof, nor any of their employees, make any warranty, express or implied, or assumes any legal liability or responsibility for the accuracy, completeness, or usefulness of any information, apparatus, product, or process disclosed, or represents that its use would not infringe privately owned rights. Reference herein to any specific commercial product, process, or service by trade name, trademark, manufacturer, or otherwise does not necessarily constitute or imply its endorsement, recommendation, or favoring by the United States Government or any agency thereof. The views and opinions of authors expressed herein do not necessarily state or reflect those of the United States Government or any agency thereof. 


\section{DISCLAIMER}

Portions of this document may be illegible in electronic image products. Images are produced from the best available original document. 


\section{Summary}

In January 1993, Pacific Northwest National Laboratory (PNNL) established an area monitoring dosimeter program in accordance with Article 514 of the Department of Energy (DOE) Radiological Control Manual (RCM). The purpose of the program was to minimize the number of areas requiring issuance of personnel dosimeters and to demonstrate that doses outside Radiological Buffer Areas are negligible. In accordance with 10 CFR Part 835.402 (a) (1)-(4) and Article 511.1 of the RCM, personnel dosimetry shall be provided to 1) radiological workers who are likely to receive at least $100 \mathrm{mrem}$ annually and 2) declared pregnant workers, minors, and members of the public who are likely to receive at least 50 mrem annually. Program results for calendar years 1993-1997 confirmed that personnel dosimetry was not needed for individuals located in areas monitored by the program.

A total of 97 area thermoluminescent dosimeters (TLDs) were placed in PNNL facilities during calendar year 1998. The TLDs were exchanged and analyzed quarterly. All routine area monitoring TLD results were less than 50 mrem annually after correcting for worker occupancy. The results support the conclusion that personnel dosimeters are not necessary for staff, declared pregnant workers, minors, or members of the public in these monitored areas. 



\section{Contents}

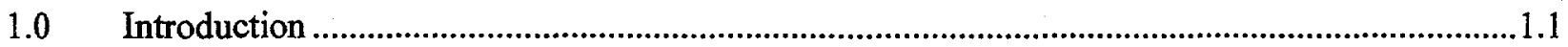

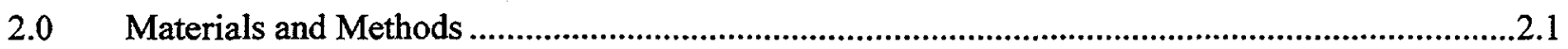

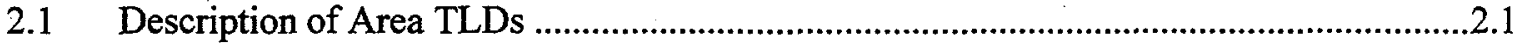

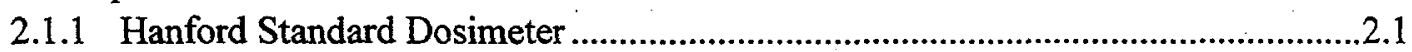

2.1.2 Hanford Combination Neutron Dosimeter ......................................................2.2

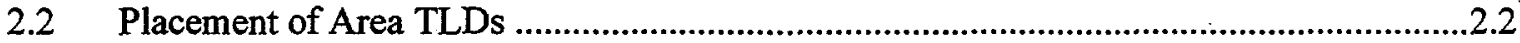

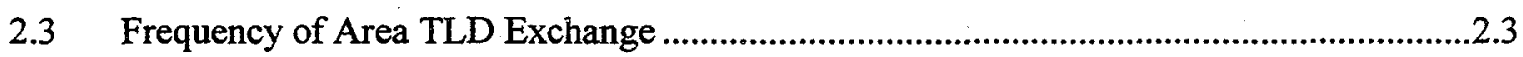

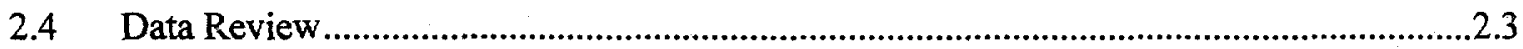

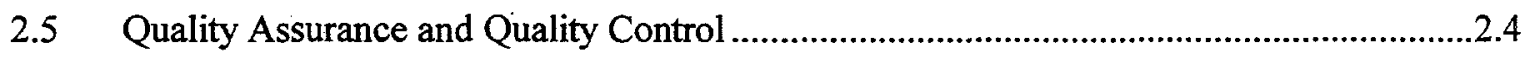

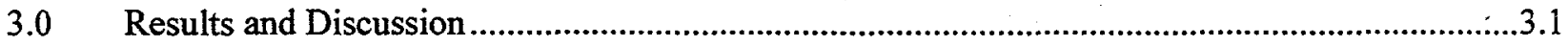

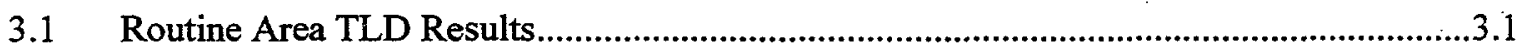

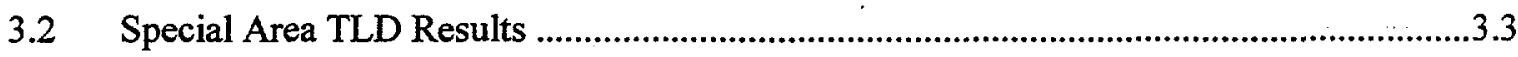

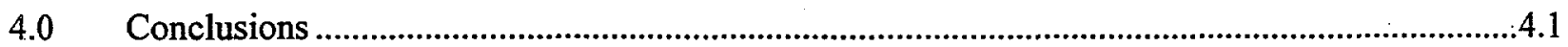

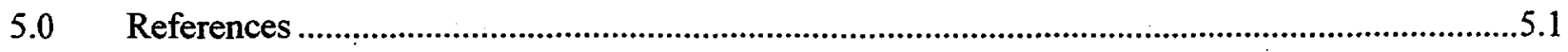

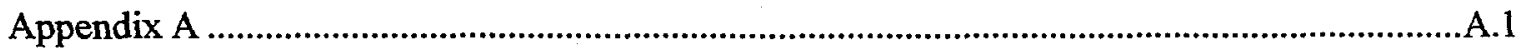

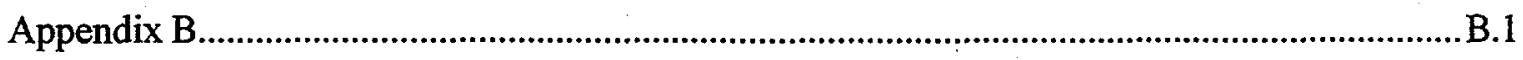

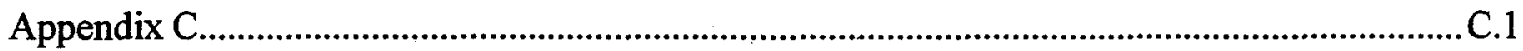




\subsection{Introduction}

The Department of Energy (DOE) Radiological Control Manual (RCM)(DOE 1994), first issued in 1992, establishes practices for radiological control activities at DOE facilities. Article 514 of the RCM discusses the establishment and maintenance of a comprehensive area dosimeter monitoring program to minimize the number of areas requiring issuance of personnel dosimeters and to demonstrate that doses outside of Radiological Buffer Areas are negligible. This program will also help demonstrate compliance with 10 CFR Part 835.401(a)(3), 401(a)(6), 402(a)(3), 401(a)(4), and 1003(b). As discussed in Article 514 , area monitoring dosimeters

- shall be used to record and document radiation levels in routinely occupied areas adjacent to areas where radiation or operations with radiation exist (not applicable when the radiation arises solely from low-energy beta sources such as ${ }^{14} \mathrm{C}$ or ${ }^{3} \mathrm{H}$ )

- should be used in Radiologically Controlled Areas to supplement existing monitoring programs and to provide data in the event of an emergency

- should be used to support dosimetry investigations where personnel express concern about their work environment and exposure to ionizing radiation.

In January 1993, Pacific Northwest National Laboratory (PNNL) ${ }^{(1)}$ established an area monitoring thermoluminescent dosimeter (TLD) program in accordance with Article 514 of the RCM. The program was conducted as outlined by Bivins ${ }^{(1)}$ during calendar years (CY) 1993 and 1994. The program is now implemented according to RCP-5.1.04, "Area Monitoring TLD Program," issued in PNL-MA-266, PNL Radiological Control Implementing Procedures. Program results for CY 1993/1994, CY 1995, CY 1996, and CY 1997 are found in Bivins and Stoetzel (1996a), Bivins and Stoetzel (1996b), Bivins and Stoetzel (1997), and Bivins and Stoetzel (1998), respectively. Data from the program were also used to support the PNNL As Low As Reasonably Achievable (ALARA) program.

The materials and methods used in collecting area monitoring TLD data and program results for CY 1998 are presented in this report. Neutron dose readings from the area TLDs were included in Section 3.0 of this report. An evaluation of the accuracy of neutron dose data was included in this section. Although neutron dose data was available for previous years, it was not included in previous annual reports.

\footnotetext{
(1) The Pacific Northwest National Laboratory is operated for the U.S. Department of Energy by Battelle under Contract DE-AC06-76RLO 1830. Battelle also owns and operates private facilities near the Hanford Site.

(2)Bivins, S.R. February 24, 1993. Letter Report to D.P. Higby entitled "Area Monitoring Dosimeter." Pacific Northwest National Laboratory, Richland, Washington.
} 


\subsection{Materials and Methods}

This section provides information on the type of TLDs used in the program, how they were located in the field, and frequency of exchange. Derivation of the investigation level, which triggers an evaluation into the potential cause of a reading, is also provided.

\subsection{Description of Area TLDs}

The Hanford Standard Dosimeter and the Hanford Combination Neutron Dosimeter were used as dosimeters for this program during CY 1998. The Hanford Standard Dosimeter was positioned at all but one location ( 3745 vault). The 3745 vault was used for storage of neutron sources; therefore, a Hanford Combination Neutron Dosimeter was positioned near the vault.

A brief description of each type of dosimeter is presented below. Appendix A provides a description of TLD processing, calibration, and the dose algorithm used in determining doses. A more detailed description of each dosimeter and processing system can be found in PNL-MA-568, Hanford External Dosimetry Project Manual (October 1996 issue).

\subsubsection{Hanford Standard Dosimeter}

This dosimeter has also been accredited by the DOE Laboratory Accreditation Program (DOELAP) and is known commercially as a Harshaw $\mathbf{8 8 2 5}$ dosimeter. The dosimeter contains TLD-700 chips in positions one, two, and three and a TLD-600 chip in position four. The TLD-600 chip is neutronsensitive. The chips have thicknesses of $0.38 \mathrm{~mm}\left(100 \mathrm{mg} / \mathrm{cm}^{2}\right)$ in positions one, two, and four, and 0.15 $\mathrm{mm}\left(40 \mathrm{mg} / \mathrm{cm}^{2}\right)$ in position three. The TLD holder is constructed of black plastic with the following filtration:

1. position one $-242 \mathrm{mg} / \mathrm{cm}^{2}$ ABS plastic and $91 \mathrm{mg} / \mathrm{cm}^{2}$ copper

2. position two $-1000 \mathrm{mg} / \mathrm{cm}^{2}$ acrylonitrilebutadienestyrene (ABS) plastic and Teflon.

3. position three $-8 \mathrm{mg} / \mathrm{cm}^{2}$ Teflon@ and $9 \mathrm{mg} / \mathrm{cm}^{2}$ mylar

4. position four $-240 \mathrm{mg} / \mathrm{cm}^{2} \mathrm{ABS}$ plastic and $463 \mathrm{mg} / \mathrm{cm}^{2}$ tin.

These dosimeters were read for shallow dose, deep dose, neutron dose, and eye dose. Only deep dose and neutron dose readings are discussed in this report.

\footnotetext{
${ }^{\circledR}$ Teflon is a registered trademark of E. I. Du Pont de Nemours Co., Inc., Wilmington, Delaware.
} 


\subsubsection{Hanford Combination Neutron Dosimeter}

This dosimeter consists of three components - 1) a beta-photon TLD, 2) an albedo neutron TLD, and 3) two CR-39 track-etch dosimeter foils. The albedo neutron TLD is currently used to assess neutron dose rather than the CR-39 track-etch dosimeter foils. The beta-photon TLD is the Harshaw 8825 dosimeter. The albedo neutron TLD is the Harshaw 8816 dosimeter, which contains three TLD-600 phosphors and one TLD-700 phosphor. This albedo TLD has the following filter configurations:

- TLD-700 \#1 (tin filters on the front and back)

- TLD-600 \#2 (cadmium filter on front and tin filter on the back)

- TLD-600\#3 (tin filter on front and cadmium filter on back)

- TLD-600 \#4 (tin filters on front and back)

These dosimeters were read for shallow dose, deep dose, neutron dose, and eye dose. Only deep dose and neutron dose readings are discussed in this report.

\subsection{Placement of Area TLDs}

Area TLDs were placed in the following PNNL facilities (DOE-owned, DOE-leased, and Battelle private):

- all 300 Area PNNL facilities where staff worked at least eight hours per month

- all PNNL facilities where staff conducted radiological work (i.e., had a current Radiological Work Permit)

- all PNNL facilities that were located within $15 \mathrm{~m}(\sim 50 \mathrm{ft})$ of another facility (including those of other Hanford Site contractors) containing a radiological area (indoors or outdoors).

TLDs positioned as discussed above are referred to as "routine" area TLDs in this report. Area TLDs were also positioned in facilities as approved by the Radiological Control organization for special situations such as ALARA evaluations. In this report, these are referred to as "special" area TLDs. 
A list of routine and special area TLD locations is included as Appendix B. The number of area TLDs in each facility was determined according to the following criteria:

- at least one area TLD per facility

- one additional area TLD for every 25 staff members for facilities that require area TLDs but do not contain a Radiologically Controlled Area or a radiological area

- one additional area TLD for every 15 staff members for facilities that require area TLDs and contain a Radiologically Controlled Area or a radiological area

Additional area TLDs were positioned as determined by the Radiological Control organization.

Each Hanford Standard Dosimeter used as an area TLD was positioned facing the potential source of exposure. If the potential source of exposure was from within the facility, then the area TLD was placed on the wall opposite the potential source. If the potential source of exposure was located outside the facility, then the area TLD was placed on the inside surface of the exterior wall facing the potential source. The TLDs were placed 1 to $2 \mathrm{~m} \mathrm{(3} \mathrm{to} 6 \mathrm{ft}$ ) from the floor, depending on whether staff in the area would be standing or seated.

Each Hanford Combination Neutron Dosimeter used as an area TLD was placed on the front-face of a 5 -gallon carboy filled with water. The neutron portion of the dosimeter was at least $7.5 \mathrm{~cm}$ ( 3 inches) from any edge of the carboy. The physical size and weight of the 5-gallon carboy limits the locations for positioning this dosimeter.

Each area TLD was identified with an attached bar code label containing a facility ID (e.g., 337 LOC.5) and a TLD identification number beginning with the letter " $A$ " to denote an area TLD followed by a four-digit number (e.g., A3014).

\subsection{Frequency of Area TLD Exchange}

All area TLDs were scheduled to be exchanged and analyzed quarterly. The area monitoring TLD procedure allows for a facility manager to request a special exchange for any TLD in his/her facility. The Safety \& Health Manager may also request a special exchange for area TLDs in any facility. Any area TLD changed out was immediately replaced with another area TLD unless the area TLD location was being discontinued.

\subsection{Data Review}

Any area TLD results greater than or equal to $40 \mathrm{mrem}$ in a quarter was investigated. This action level was established to ensure that an individual would not likely receive greater than 50 mrem annually (the trigger level for requiring personnel dosimetry for declared pregnant workers, minors, and members of the public). The investigation level of 40 mrem per quarter was derived by dividing the $50 \mathrm{mrem}$ annual limit 
by four and adjusting for worker occupancy. The area TLDs were exposed for approximately $8760 \mathrm{~h}$ annually; individual occupancy was assumed to be $2000 \mathrm{~h}(8 \mathrm{~h} / \mathrm{d}, 5 \mathrm{~d} / \mathrm{wk}$, and $50 \mathrm{wk} / \mathrm{yr})$. Therefore, the occupancy-corrected quarterly limit is as follows:

Quarterly limit $=(50 \mathrm{mrem} / 4)(8760 \mathrm{~h} / 2000 \mathrm{~h})=55 \mathrm{mrem}$

The 55-mrem calculated quarterly limit was reduced to $40 \mathrm{mrem}$ to allow for such factors as processing time, processing errors, the potential for individuals to be present more than $2000 \mathrm{~h}$ annually, and the potential for maximum exposure rates occurring during occupancy hours.

\subsection{Quality Assurance and Quality Control}

The Hanford External Dosimetry Project (HEDP) performed the measurements of the area TLDs. The HEDP laboratory is DOELAP accredited. Quality assurance and quality control programs are conducted in accordance with Section 5 of PNL-MA-568 and Section 3 of PNL-MA-842, Hanford External Dosimetry Project Technical Basis Manual (September 1998 issue). 


\subsection{Results and Discussion}

Table 3.1 summarizes area monitoring TLD results for CY 1998. Quarterly area monitoring TLD results are grouped into dose ranges (i.e., $\leq 10 \mathrm{mrem}$; $>10 \mathrm{mrem}$ but $<40 \mathrm{mrem}$; $<40 \mathrm{mrem}$ ). In three locations, quarterly area monitoring TLD results for routine locations exceeded the quarterly investigation level of $40 \mathrm{mrem}$; however, none of these locations had potential personnel exposures of $50 \mathrm{mrem}$ after considering worker occupancy. The results support the conclusion that personnel dosimeters are not necessary for staff in the areas monitored by the area TLDs.

Table 3.1. Summary of Area Monitoring TLD Results, CY 1998

\begin{tabular}{|c|c|}
\hline 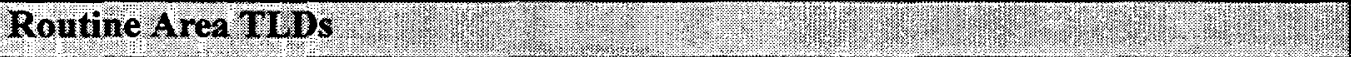 & Quantity \\
\hline - Number of Area TLD Locations & 97 \\
\hline - Total Number of Area TLDs Analyzed ${ }^{(a)}$ & 361 \\
\hline \multicolumn{2}{|l|}{ - Area TLD Results by Dose Range } \\
\hline$\leq 10 \mathrm{mrem}$ & 332 \\
\hline$>10$ mrem but $<40$ mrem & 19 \\
\hline$\geq 40 \mathrm{mrem}^{(\mathrm{b})}$ & 10 \\
\hline \multicolumn{2}{|l|}{ Special Area TIDs } \\
\hline - Number of Area TLD Locations & 0 . \\
\hline - Total Number of Area TLDs Analyzed & 0 \\
\hline \multicolumn{2}{|l|}{ - Area TLD Results by Dose Range } \\
\hline $10 \mathrm{mrem}$ & 0 \\
\hline$>10$ mrem but $<40$ mrem & 0 \\
\hline $40 \mathrm{mrem}^{(\mathrm{b})}$ & 0 \\
\hline $\begin{array}{l}\text { (a) The total does not equal } 388 \text { (four times the number of TLD locations) because loca } \\
\text { started and terminated at various times throughout the year, and several samples were } 1 \\
\text { (b) The quarterly investigation level was } 40 \text { mrem. }\end{array}$ & $\begin{array}{l}\text { ions were } \\
\text { st. }\end{array}$ \\
\hline
\end{tabular}

Individual area monitoring TLD results for each quarter as well as annual totals are presented in Appendix C. The results in Appendix $\mathrm{C}$ are not corrected for worker occupancy. Assuming workers to be present $2000 \mathrm{~h} / \mathrm{yr}$, results should be multiplied by 0.23 to correct for worker occupancy.

\subsection{Routine Area TLD Results}

Quarterly area monitoring TLD results for facilities located outside the 300 Area (622R, 747A, 747A Trl, 2400 Stevens, EMSL, ESB, HS-1, LSL-II, PSL, RTL, and Sigma V) were $\leq 10$ mrem. The four 
locations with quarterly results greater than or equal to the $40 \mathrm{mrem}$ "investigation level" were located in the 300 Area. Reviews were conducted on these locations and results are summarized below.

- TLD ID\# A3048 (3720 Loc. 2) was located on the bulletin board in the lunchroom of the 3720 Building. The total measured deep dose was 30 mrem for CY 1993, 120 mrem for CY 1994, 180 mrem for CY 1995, $146 \mathrm{mrem}$ for CY 1996, and $486 \mathrm{mrem}$ for CY 1997. Total measured deep dose for CY 1998 was $478 \mathrm{mrem}$; about the same as CY 1997. As documented in past annual reports, the cause of the elevated readings was radioactive material stored in a shielded glovebox in a laboratory across the hall from the lunchroom. Based on the elevated readings, the cognizant Radiological Control Technician (RCT) Supervisor added the lunchroom to the daily routines for the facility and directed researchers to notify the Radiological Control organization before moving any materials within the shielded glovebox. Daily routines using a microrem meter showed contact reading on the wall, where the area TLD was located, to range from 50 to $100 \mu \mathrm{mrem} / \mathrm{h}$. Readings dropped off to approximately $30 \mu \mathrm{rem} / \mathrm{h}$ several feet from the wall. General background readings in the lunchroom were about 10-15 $\mu \mathrm{mrem} / \mathrm{h}$; therefore, there was no exposure concern to staff in the lunchroom. The projected dose to staff in the lunchroom is less than the $50 \mathrm{mrem}$ annual dose requiring personnel dosimetry for a declared pregnant worker, a minor, or a member of the public.

Most of the radioactive material in the shielded glovebox was shipped to another facility during April 1999. Microrem readings on contact with the wall near the area TLD location were reduced by a factor of 4 (i.e., 12-25 $\mu \mathrm{mrem} / \mathrm{h}$ ). The first quarter of CY 1999 should be the last quarter with readings exceeding the 40 mrem investigation level.

- TLD ID\# A3062 (325 Loc. 2) was located in Room 5 of the mezzanine of 325 Building on the north wall about chest height. The total measured deep dose for CY 1993-CY 1996 ranged from 20-58 mrem. Total measured deep dose increased to $108 \mathrm{mrem}$ for CY 1997 and to $340 \mathrm{mrem}$ for CY 1998. The upward trend in dose for the past two years is due to increased waste handling and storage activities in the basement of 325 . Waste is frequently stored along the south wall of the basement just below Room 5. Differences in readings between the CY 1998 quarters are likely due to the movement of waste in and out of the basement. Routine surveys are taken in the mezzanine annually. The last survey conducted during October 1998 showed $\mu$ mrem readings ranging from 5 to 28 $\mu \mathrm{mrem} / \mathrm{h}$, which were below the $50 \mu \mathrm{mrem} / \mathrm{h}$ level requiring posting as a Radiological Buffer Area. Based on the area TLD results for CY 1998, an individual spending 2000 hours/y in Room 5 near the north wall could have received $78 \mathrm{mrem}$. Occupancy by a member of the public, minor, or pregnant worker is not likely to exceed 0.5 , which would be equivalent to $<40 \mathrm{mrem}$ annually and would not require dosimetry.

- TLD ID\# A3175 (325 Loc. 5) was located in the lunchroom area of the east equipment room located on the second floor of the 325 Building. This location was initiated the second quarter of CY 1997. The second quarter "deep dose" result for CY 1998 was 42 mrem. Deep dose results for the other quarters were less than the 40 mrem investigation level $(33,38$, and $11 \mathrm{mrem})$. The total annual deep dose was $124 \mathrm{mrem}$. 
The neutron-sensitive TLD- 600 chip of the area dosimeters showed positive readings (i.e., ranged from 20-36 mrem per quarter) since placed at this location the second quarter of CY 1997. This was the only area TLD location that showed positive neutron dose results on a Hanford Standard Dosimeter for CY 1998. The likely source of the neutron dose was from Room 503 located beneath the east equipment room. Room 503 contains a fissile materials storage area. The neutron dose results for the area dosimeters are based on a calibration on phantom to unmoderated neutrons from bare ${ }^{252} \mathrm{Cf}$. The neutrons reaching this area TLD location will be moderated by intervening shielding and building material; therefore, a calibration was performed with the dosimeter in air to a ${ }^{252} \mathrm{Cf}$ source moderated by a $30-\mathrm{cm}$-diameter sphere of $\mathrm{D}_{2} \mathrm{O}$. This calibration showed that the reported neutron dose results in Appendix $\mathrm{C}$ should be divided by a factor of 2.66 to obtain a more accurate neutron dose result. With the application of this correction factor the corrected annual neutron dose would be $\sim 45$ mrem.

Area TLD results for CY 1997 were comparable to the CY 1998 results; there was no noticeable upward trend of results. Summing the deep dose and neutron doses for CY 1998 and conservatively assuming an individual to be exposed for 2000 hours, the maximum annual dose to an individual would be $\sim 40 \mathrm{mrem}$. This dose is below the $50 \mathrm{mrem}$ annual dose, which requires personnel dosimetry for a declared pregnant worker, a minor, or a member of the public.

- TLD ID\# A3185 (3745 Loc. 2) was located at the entrance to the radioactive material storage vault in the 3745 Building. This area TLD was a Hanford Combination Neutron Dosimeter and was placed in the field starting the third quarter of CY 1998. The TLD was located on the floor in front of the vault. Results for the third quarter of CY 1998 showed a deep dose of $49 \mathrm{mrem}$ and a neutron dose of 97 mrem. Results for the fourth quarter decreased to 13 mrem deep dose and 28 mrem neutron dose. A Hanford Standard Dosimeter, area TLD (TLD ID\# A3158), located about 10 feet from A3185 showed zero dose for CY 1997 and CY 1998. TLD ID\# A3050 is located in the Counting Laboratory (north end of 3745 Building). This is the only routinely occupied area in 3745 Building and has had 0 mrem area TLD readings since it was initiated in CY 1993. Therefore, doses to a member of the public, minor, or pregnant worker would be less than 50 mrem annually.

All area TLDs will be removed from 3745 Building as it is no longer an occupied facility. The Counting Laboratory was moved to 326 Building during the first quarter of 1999.

\subsection{Special Area TLD Results}

No special area TLDs were positioned in the field during CY 1998. 


\subsection{Conclusions}

The area monitoring TLD program for CY 1998 was a useful tool in determining exposure trends in work areas located outside radiological areas. All routine area monitoring TLD results were less than 50 mrem annually after correcting for worker occupancy. The results support the conclusion that personnel dosimeters are not required for staff in these monitored areas. 


\subsection{References}

Bivins, S. R. and G. A. Stoetzel. 1996a. Area Monitoring Dosimeter Program for the Pacific Northwest National Laboratory: Results for CY 1993 and CY 1994. PNNL-11088, March 1996, Pacific Northwest. National Laboratory, Richland, Washington.

Bivins, S. R. and G. A. Stoetzel. 1996b. Area Monitoring Dosimeter Program for the Pacific Northwest National Laboratory: Results for CY 1995. PNNL-11185, May 1996, Pacific Northwest National Laboratory, Richland, Washington.

Bivins, S. R. and G. A. Stoetzel. 1997. Area Monitoring Dosimeter Program for the Pacific Northwest National Laboratory: Results for CY 1996. PNNL-11594, June 1997, Pacific Northwest National Laboratory, Richland, Washington.

Bivins, S. R. and G. A. Stoetzel. 1998. Area Monitoring Dosimeter Program for the Pacific Northwest National Laboratory: Results for CY 1997. PNNL-11594, June 1997, Pacific Northwest National Laboratory, Richland, Washington.

PNL-MA-266, PNNL Radiological Control Implementing Procedures.

PNL-MA-568, Hanford External Dosimetry Project Manual.

PNL-MA-842, Hanford External Dosimetry Project Technical Basis Manual.

U.S. Department of Energy (DOE). 1994. Radiological Control Manual. DOE/EH-0256T, Rev. 1, Washington, D.C. 


\section{Appendix A}

Area TLD - Processing, Calibration, and Dose Assessment 


\section{Appendix A}

\section{Area TLD - Processing, Calibration, and Dose Assessment}

\section{A.1 Processing}

Harshaw 8800 series automated reader systems were used to process the area TLDs (i.e., Hanford Standard Dosimeter and Hanford Combination Neutron Dosimeter). Automated processing steps included the following:

- Pre-issue reader annealings, in which each dosimeter card is processed through the automated reader systems to remove any remaining residual signal from past occupational exposure or environmental background radiation. Each dosimeter card is annealed at $80^{\circ} \mathrm{C}$ for $16 \mathrm{~h}$ before being issued.

- Reader processing, in which the reader heats all chips simultaneously at a rate of $25^{\circ} \mathrm{C} / \mathrm{s}$ until a maximum temperature of $300^{\circ} \mathrm{C}$ is obtained.

- Glow-curve recording, in which the glow curve is recorded for all dosimeters and stored for a period of approximately $2 \mathrm{yr}$.

\section{A.2 Calibration}

Area TLDs were calibrated using sources that were traceable to the National Institute of Standards and Technology (NIST). The primary calibration was the deep dose from an on-phantom ${ }^{137} \mathrm{Cs}$ exposure.

\section{A.3 Dose Assessment}

The contribution to the area TLD from naturally occurring environmental radiation was determined using the following equation:

$E_{i}=G_{i}(F D-B D)$

where: $\mathrm{E}_{\mathrm{i}} \quad$ = estimated environmental background for chip i $\left({ }^{60} \mathrm{Co} \mathrm{mR}\right.$-equivalent $)$

$\mathrm{G}_{\mathrm{i}} \quad=$ background growth rate $(\mathrm{mR} / \mathrm{d})$

FD = field cycle days (days between previous and current processing date)

$\mathrm{BD}=$ blank days (mean days between previous and current processing for blank cards). 
The adjusted chip readings are calculated using the following equation:

$$
D_{i}=\frac{X_{i} B_{i} E_{i}}{\left(R R F_{i}^{*} F_{i}\right)}
$$

where: $D_{i} \quad=$ adjusted chip reading for chip $i\left({ }^{137} \mathrm{C}\right.$ rem-equivalent)

$\mathrm{X}_{\mathrm{i}} \quad=$ calibrated chip reading for chip $\mathrm{i}\left({ }^{60} \mathrm{Co} \mathrm{mR}\right.$-equivalent $)$

$\mathrm{Bi}=$ mean calibrated chip i reading from blank cards $\left({ }^{60} \mathrm{Co} \mathrm{mR}\right.$-equivalent $)$

$\mathrm{E}_{\mathrm{i}} \quad=$ estimated environmental background for chip i $\left({ }^{60} \mathrm{Co} \mathrm{mR}\right.$-equivalent $)$

$R R F_{i}={ }^{137} \mathrm{Cs}$ relative response factor $(\mathrm{RRF})$ for chip $\mathrm{i}(\mathrm{mR} / \mathrm{rem})$

$F_{i} \quad=$ fade factor for chip $i$

Area TLD readings were provided for shallow dose, deep dose, neutron dose, and eye dose. Only deep dose and neutron results were included for discussion in this report.

\section{A.4 Dose Algorithm}

Dose algorithms for the Hanford Standard Dosimeter and Hanford Combination Neutron Dosimeter can be found in Section 8 of PNL-MA-568.

\section{A.5 Quality Control Program}

Quality assurance and quality control programs are conducted in accordance with Section 5 of PNLMA-568 and Section 3 of PNL-MA-842. 


\section{Appendix B}

\section{Locations of Area Monitoring TLDs}




\section{Appendix B}

\section{Locations of Area Monitoring TLDs}

\begin{tabular}{|c|c|c|c|}
\hline BLDG & TLDD\# & Location ID \# & Description of Location \\
\hline & & Routine TLDs & \\
\hline $305-B$ & A3001 & LOC. 1 & South wall of $\mathrm{Rm} 2$ near vending machine \\
\hline $306-W$ & $\mathrm{~A} 3034$ & LOC. 1 & Main entrance on first bulletin board \\
\hline $306-W$ & $\mathrm{~A} 3035$ & LOC. 2 & Second floor lunchroom \\
\hline $306-W$ & A:3036 & LOC. 3 & First floor - Rm 131 \\
\hline 318 & A3039 & LOC. 1 & Front lobby \\
\hline 318 & A3040 & LOC. 2 & Main corridor of second floor across from $\mathrm{Rm} 202$ \\
\hline 318 & A3041 & LOC. 3 & Main corridor outside instrument receiving \\
\hline 318 & A3022 & TRL. 4 & Bulletin board on the north wall (main entrance) \\
\hline 320 & A3042 & LOC. 1 & Lobby \\
\hline 320 & A3043 & LOC. 2 & Basement on bulletin board outside of $\mathrm{Rm} 5$ on east wall \\
\hline 325 & A3061 & LOC. 1 & Main lobby near north door \\
\hline 325 & $\mathrm{~A} 3062$ & LOC. 2 & Mezzanine, $\mathrm{Rm}$ 5, north wall (chest height) \\
\hline 325 & A3063 & LOC. 3 & Second floor - outside of $\mathrm{Rm} 944$ \\
\hline 325 & $\mathrm{~A} 3174$ & LOC. 4 & Lunchroom (second floor) \\
\hline 325 & A3175 & LOC. 5 & East equipment rm (second floor, lunch area) \\
\hline 325 & $\mathrm{~A} 3176$ & LOC. 6 & Copy rm (second floor) \\
\hline 326 & A3064 & LOC. 1 & First floor - bulletin board in copy area (Rm 15) \\
\hline 326 & A3065 & LOC: 2 & First floor - in front of exit door to basement \\
\hline 326 & A3066 & LOC. 3 & First floor - in corridor across from $\mathrm{Rm} 48-\mathrm{B}$ \\
\hline 326 & $\mathrm{~A} 3067$ & LOC. 4 & Second floor - lunchroom bulletin board \\
\hline 326 & A3068 & LOC. 5 & Second floor - corridor near Rm 40-C \\
\hline 326 & $\mathrm{~A} 3157$ & LOC. 6 & Basement - Rm 14A bulletin board \\
\hline 326 & A3178 & LOC. 7 & $\mathrm{Rm} 37 \mathrm{~B}$ (second floor, east wall) \\
\hline 329 & A3071 & LOC. 1 & Lunchroom \\
\hline 329 & A3072 & LOC. 2 & $\mathrm{Rm} 115$ - east wall \\
\hline 329 & $\mathrm{~A} 3074$ & LOC. 4 & North-south hallway (Rm 2) \\
\hline 329 & $\mathrm{~A} 3075$ & LOC. 5 & North-south hallway (Rm 6-C) \\
\hline 329 & $\mathrm{~A} 3173$ & LOC. 8 & Rm 129 (above sink) \\
\hline
\end{tabular}

B. 1 


\begin{tabular}{|c|c|c|c|}
\hline BLDG & TLD W \# & Tocation ID \# & Description of Location \\
\hline 331 & A3044 & LOC. 1 & First floor - mail room \\
\hline 331 & $\mathrm{~A} 3045$ & LOC. 2 & Second floor hallway on bulletin board outside of $\mathrm{Rm} 22$ \\
\hline 331 & $\mathrm{~A} 3046$ & LOC. 3 & Third floor - Rm 45 \\
\hline $336-1$ & A3073 & LOC:1 & Bulletin board in $R m 5$ on east wall at entrance to $R m 6$ \\
\hline 337 & $\mathrm{A3080}$ & LOC. 1 & First floor south - west wall of Rm 1114 \\
\hline 337 & A3081 & LOC. 2 & First floor north - east wall of $\mathrm{Rm} 1225$ \\
\hline 337 & $\mathrm{~A} 3082$ & LOC. 3 & Second floor south - west wall of $\mathrm{Rm} 2112$ \\
\hline 337 & $\mathrm{~A} 3083$ & LOC. 4 & Second floor north - north wall of Rm 2213 \\
\hline 337 & A3084 & LOC. 5 & Third floor south - Rm 3124 \\
\hline 337 & $\mathrm{~A} 3085$ & LOC. 6 & Third floor north - Mt. Rainier Rm \\
\hline 337 & A3155 & LOC. 7 & Duplicating rm - north wall \\
\hline 338 & $\mathrm{~A} 3177$ & LOC. 1 & Conference rm \\
\hline 350 & $\mathrm{~A} 3004$ & LOC. 1 & Bulletin board in $\mathrm{Rm} 137$ \\
\hline 350 & $\mathrm{~A} 3005$ & LOC. 2 & Bulletin board between $\mathrm{Rm} 158$ and $\mathrm{Rm} 175$ \\
\hline $622-\mathrm{R}$ & A3086 & LOC. 1 & $\mathrm{Rm} 110$ by red phone \\
\hline $622-\mathrm{R}$ & A3087 & LOC. 2 & Exit sign in front of men's room \\
\hline $747-\mathrm{A}$ & A3088 & LOC. 1 & Bulletin board on west wall by scale \\
\hline $747-A$ & A3089 & TRL.1, LOC. 1 & Bulletin board by south door \\
\hline 2400 & A3113 & LOC. 1 & Secretary's desk located in main entrance \\
\hline 2400 & A3114 & LOC. 2 & Bulletin board in entry way to $\mathrm{Rm} 1414$ \\
\hline 2400 & $\mathrm{~A} 3115$ & LOC. 3 & High-bay bulletin board in entry to Lab 1445 \\
\hline 2400 & A3116 & LOC. 4 & Second floor on bulletin board outside of $\mathrm{Rm} 2428$ \\
\hline $3718-\mathrm{A}$ & A3006 & LOC. 1 & Bulletin board outside of main office \\
\hline $3718-\mathrm{B}$ & $\mathrm{A} 3007$ & LOC. 1 & Above phone on north wall \\
\hline $3718-G$ & A3119 & LOC. 1 & North wall of warehouse office \\
\hline 3720 & A3047 & LOC. 1 & North and south corridor across from Rm 221 \\
\hline 3720 & A3048 & LOC. 2 & Bulletin board in lunchroom ( $\mathrm{Rm} 401)$, north wall \\
\hline 3730 & A3049 & LOC. 1 & Desk area near computers \\
\hline 3745 & A3050 & LOC. 1 & Counting Laboratory - south wall \\
\hline 3745 & A3158 & LOC. 2 & On wall about $10 \mathrm{ft}$ from vault \\
\hline 3745 & A3185 & LOC. 2 & In front of vault at floor level \\
\hline 3760 & A3009 & LOC. 1 & Lobby \\
\hline 3760 & A3010 & LOC. 2 & Second floor Rm 215 (SE cubicle) \\
\hline 3760 & A3011 & LOC. 3 & Second floor - copy room \\
\hline EMSL & A3093 & LOC. 1 & Accelerator Room (north wall) \\
\hline
\end{tabular}




\begin{tabular}{|c|c|c|c|}
\hline BLDG & $\operatorname{Tid~D~} \#$ & Location $1 \mathrm{D} \#$ & Description of L ocation \\
\hline EMSL & A3094 & LOC. 2 & Accelerator Rm (east wall) \\
\hline EMSL & A3095 & LOC. 3 & Accelerator Rm (south wall enclosure) \\
\hline EMSL & A3096 & LOC. 4 & Accelerator Rm (south wall) \\
\hline EMSL & A3097 & LOC. 5 & Accelerator Rm (west wall) \\
\hline EMSL & A3098 & LOC. 6 & Accelerator Rm (control console) \\
\hline ESB & A3091 & LOC. 1 & Inside of $\mathrm{Rm} 14$ \\
\hline ESB & A3092 & LOC. 2 & Entry way to $\mathrm{Rm} 31$ \\
\hline HS-1 & $\mathrm{A} 3179$ & LOC. 1 & Rm 88 - west wall \\
\hline HS-1 & $\mathrm{A} 3180$ & LOC. 2 & $\mathrm{Rm} 88$ - west wall near floor \\
\hline HS-1 & $\mathrm{A} 3181$ & LOC. 3 & Rm 88 - north wall \\
\hline HS-1 & A3182 & LOC. 4 & Rm 94 - east wall \\
\hline LSL-II & A3167 & LOC. 1 & Lunchroom \\
\hline LSL-II & A3168 & LOC. 2 & Corridor outside of Lab 1404 \\
\hline LSL-II & A3169 & LOC. 3 & Lab 1508 \\
\hline LSL-II & A3170 & LOC. 4 & Lab 1419 \\
\hline LSL-II & $\mathrm{A} 3171$ & LOC. 5 & Office 1224 \\
\hline LSL-II & $\mathrm{A} 3172$ & LOC. 6 & Lab 1336 \\
\hline PSL & A3099 & LOC. 1 & Lab 1611 \\
\hline PSL & $\mathrm{A} 3100$ & LOC. 2 & Bulletin board in Lab 1504 \\
\hline PSL & $A 3101$ & LOC. 3 & East entrance on secretary's desk \\
\hline PSL & A3102 & LOC. 4 & Bulletin board in Lab 1304 \\
\hline PSL & A3103 & LOC. 5 & Corridor outside of Lab 315 \\
\hline RTL & $\mathrm{A} 3105$ & LOC. 1 & Lab 428 \\
\hline RTL & A3106 & LOC. 2 & Lab 328 \\
\hline RTL & $\mathrm{A} 3107$ & LOC. 3 & Lab 218 \\
\hline RTL & A3108 & LOC. 4 & Outside Room 127 Secretary office \\
\hline RTL & A3109 & LOC. 5 & Canteen above fire extinguisher \\
\hline RTL & $\mathrm{A} 3110$ & LOC. 6 & Bulletin board in $\mathrm{Rm} 21-\mathrm{A}$ \\
\hline Sigma V & A3186 & LOC. 1 & Rm 1519 - west wall \\
\hline Sigma V & A3187 & LOC. 2 & $\mathrm{Rm} 1519$ - south wall \\
\hline Sigma V & A3188 & LOC. 3 & Rm 1519 - north wall \\
\hline Sigma V & A3189 & LOC. 4 & Rm 1227 - north wall \\
\hline Sigma V & $\mathrm{A} 3190$ & LOC. 5 & Rm 1523 - west wall \\
\hline Sigma V & A3191 & LOC. 6 & Rm 1519 - ceiling \\
\hline
\end{tabular}




\section{Appendix C}

Area Monitoring TLD Results for CY 1998 


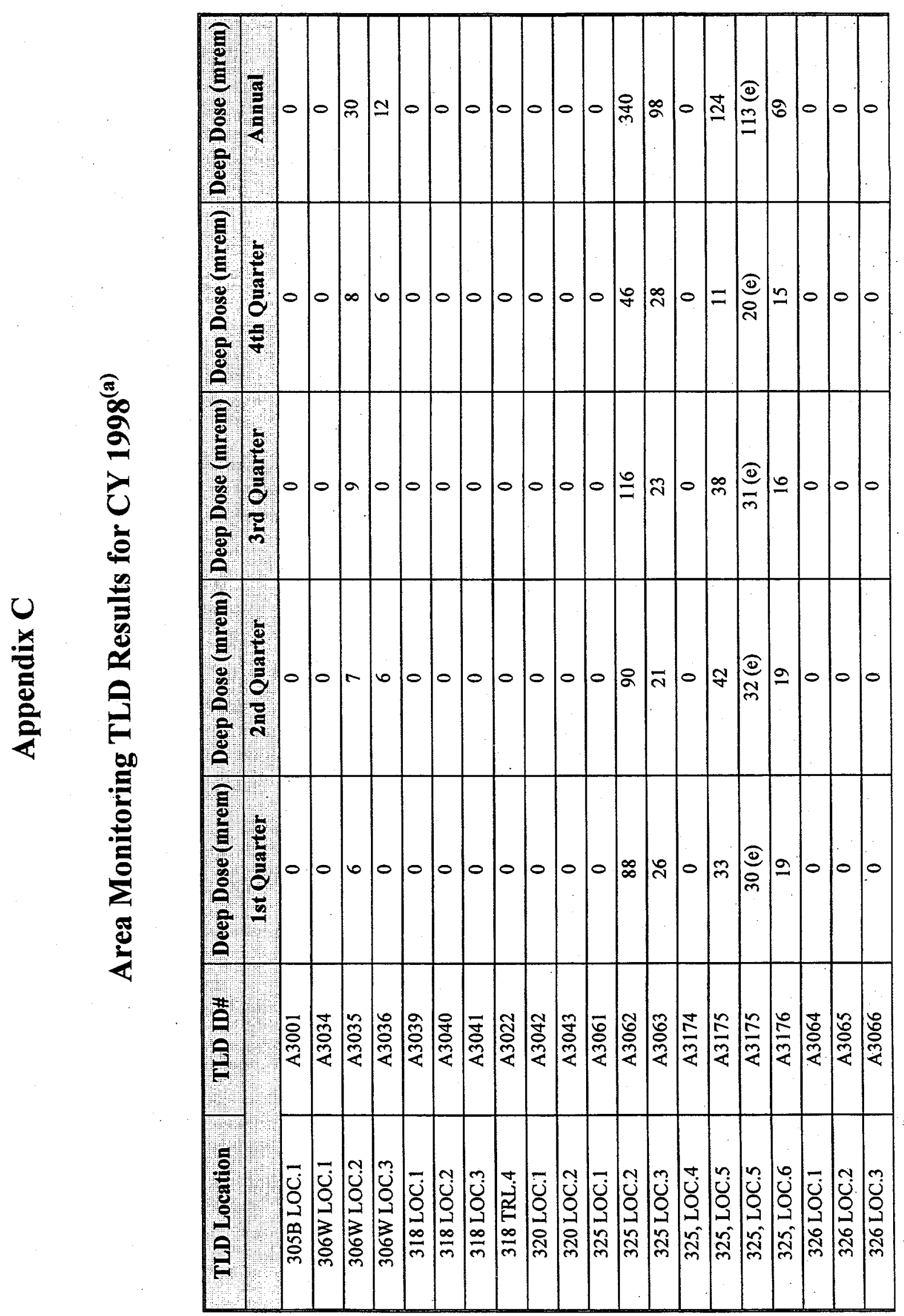




\begin{tabular}{|c|c|c|c|c|c|c|}
\hline TLD Location & TLD ID\# & Deep Dose (mrem) & Deep Dose (mrem) & Deep Dose (mrem) & Deep Dose (mrem) & Deep Dose (mrem) \\
\hline & & 1st Quarter & 2nd Quarter & 3rd Quarter & 4th Quarter & Annual \\
\hline 326 LOC. 4 & A3067 & 0 & 0 & 0 & 0 & 0 \\
\hline 326 LOC. 5 & A3068 & $\mathbf{0}$ & 0 & 0 & 0 & 0 \\
\hline 326, LOC. 6 & A3157 & 0 & 0 & 0 & 0 & 0 \\
\hline 326, LOC. 7 & A3178 & 24 & 22 & 17 & 37 & 100 \\
\hline 329 LOC. 1 & A3071 & 0 & 0 & 0 & 0 & 0 \\
\hline 329 LOC. 2 & $\mathrm{~A} 3072$ & $\overline{0}$ & 0 & 0 & 0 & 0 \\
\hline 329 LOC. 4 & A3074 & 0 & 0 & 0 & 0 & 0 \\
\hline 329 LOC. 5 & $\mathrm{~A} 3075$ & 0 & 0 & 0 & 0 & 0 \\
\hline 329, LOC. 8 & A3173 & 23 & 14 & 6 & 6 & 49 \\
\hline 331 LOC. 1 & A3044 & 0 & 0 & 0 & 0 & 0 \\
\hline 331 LOC. 2 & $\mathrm{~A} 3045$ & (b) & 0 & 0 & 0 & 0 \\
\hline 331 LOC. 3 & $\mathrm{~A} 3046$ & 0 & 0 & 0 & 0 & 0 \\
\hline $336-1$, LOC. 1 & A3073 & 0 & 0 & 0 & 0 & 0 \\
\hline 337 LOC. 1 & $\mathrm{~A} 3080$ & 0 & 0 & 0 & 0 & 0 \\
\hline 337 LOC. 2 & $\mathrm{~A} 3081$ & (b) & 0 & 0 & 0 & 0 \\
\hline 337 LOC. 3 & $\mathrm{~A} 3082$ & 0 & 0 & 0 & 5 & 5 \\
\hline 337 LOC.4 & A3083 & 0 & 0 & 0 & 0 & 0 \\
\hline 337 LOC. 5 & A3084 & 0 & 0 & 0 & 0 & 0 \\
\hline 337 LOC. 6 & $\mathrm{~A} 3085$ & 0 & 0 & 0 & 6 & 6 \\
\hline 337, LOC. 7 & $\mathrm{~A} 3155$ & 7 & 6 & 6 & 8 & 27 \\
\hline 338, LOC. 1 & A3177 & (b) & 0 & 0 & 0 & 0 \\
\hline 350 LOC. 1 & A3004 & 0 & 0 & 0 & 0 & 0 \\
\hline 350 LOC. 2 & A3005 & 0 & 0 & 0 & 0 & 0 \\
\hline 622R LOC.1 & A3086 & 7 & 8 & 7 & 6 & 28 \\
\hline 622R LOC. 2 & A3087 & 0 & 0 & 0 & 0 & 0 \\
\hline 747A LOC.1 & A3088 & 0 & 0 & 0 & 0 & 0 \\
\hline
\end{tabular}




\begin{tabular}{|c|c|c|c|c|c|c|c|c|c|c|c|c|c|c|c|c|c|c|c|c|c|c|c|c|}
\hline 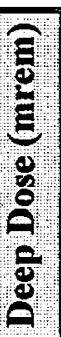 & $\frac{\pi}{8}$ & 0 & 0 & 0 & 0 & 0 & 0 & 이 & $\vec{n}$ & $0 \mid$ & $\begin{array}{l}0 \\
\end{array}$ & 10 & 0 & $\sigma$ & 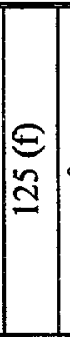 & 0.0 & 0.0 & $\equiv:$ & 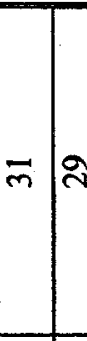 & $\stackrel{\infty}{\infty}$ & $\simeq$ & 0 . & 10 & 0 \\
\hline $\begin{array}{l}\text { E } \\
8 \\
8 \\
8 \\
\text { है }\end{array}$ & 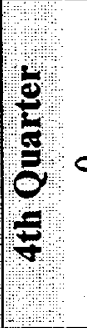 & 0 & 0 & 0 & 0 & 0 & 0 & $n$ & (ิ) & $0 \neq$ & 10 & 0 & 0 & $m$ & 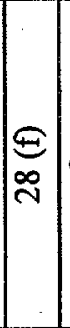 & 00 & 010 & $\ln$ & $a$ & 10 & -1 & $0\}$ & 20 & 10 \\
\hline 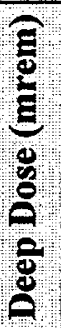 & 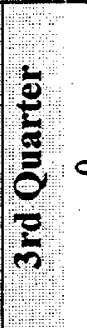 & & 0 & 0 & 0.0 & 0 & 0 & 0 & (2) & 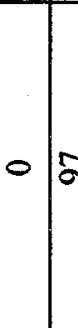 & 10 & 0 & 0 & gे & $\begin{array}{l}\mathbf{\Theta} \\
\mathbf{2}\end{array} \mid$ & 100 & 010 & 0 & \begin{tabular}{l|l|l}
0 & 0
\end{tabular} & 010 & 0 & 0 & 0 & 0 \\
\hline 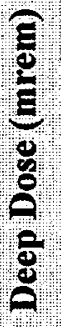 & $\frac{\Xi}{\tilde{g}}$ & 0 & 0 & 0 & 0 & 0 & 0 & 0 & 이 & 01 & i. & 0 & 0 & (ब) & (อ) & 00 & 010 & in & r & 0 in & 10 & 0 & & 10 \\
\hline 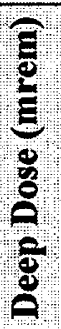 & $\frac{5}{\tilde{s}}$ & & 0 & 0 & 0 & 0 & 0 & $n$ & $\bar{m}$ & 0 & $\begin{array}{l}0 \\
2\end{array}$ & 0 & 0 & (仓) & () & 10 & 00 & $1-$ & $a 1=$ & $=r$ & in & 0 & & 10 \\
\hline है & 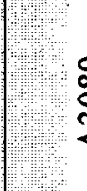 & 总 & $\frac{m}{\frac{m}{2}}$ & \begin{tabular}{l} 
\pm \\
$\vec{\alpha}$ \\
\hdashline
\end{tabular} & $\frac{n}{\vec{z}}$ & $\frac{0}{\square}$ & 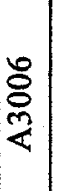 & 容 & $\stackrel{2}{\vec{\alpha}}$ & 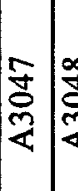 & 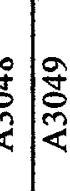 & 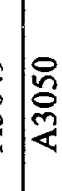 & $\frac{\infty}{2}$ & $\frac{\infty}{m}$ & $\frac{\infty}{2}$ & 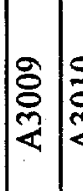 & 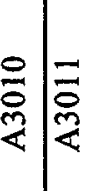 & 孚 & 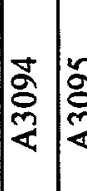 & 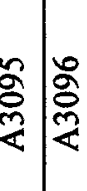 & $\mid \begin{array}{l}\hat{8} \\
\stackrel{2}{<}\end{array}$ & 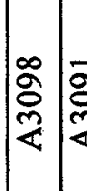 & & $\frac{\Omega}{8}$ \\
\hline 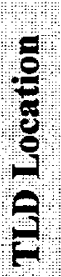 & 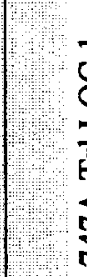 & 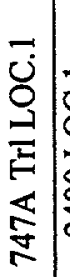 & 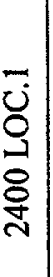 & 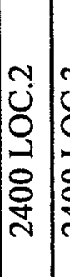 & 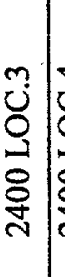 & 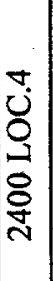 & 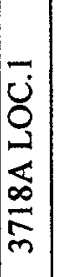 & 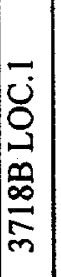 & 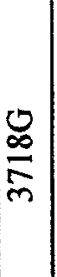 & 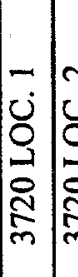 & 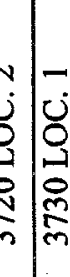 & 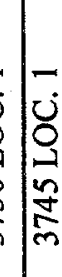 & 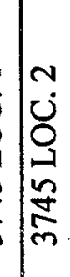 & 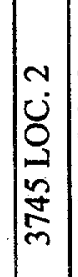 & 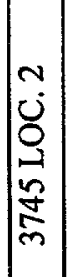 & $\mid \begin{array}{l}- \\
0 \\
0 \\
0 \\
0 \\
0 \\
0 \\
m\end{array}$ & 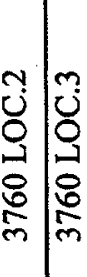 & $\mid \begin{array}{c}\vec{u} \\
\dot{O} \\
\vec{a} \\
\vec{\infty} \\
\sum_{i=1}\end{array}$ & 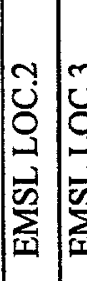 & 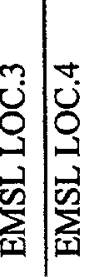 & 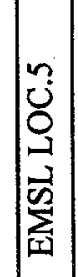 & 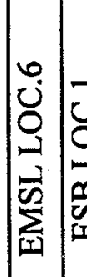 & $\mid$ & 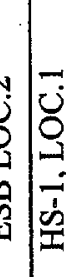 \\
\hline
\end{tabular}




\begin{tabular}{|c|c|c|c|c|c|c|}
\hline TLD Location & TLD ID\# & Deep Dose (mrem) & Deep Dose (mrem) & Deep Dose (mrem) & Deep Dose (mrem) & Deep Dose (mrem) \\
\hline & & 1st Quarter & 2nd Quarter & 3rd Quarter & 4th Quarter & Annual \\
\hline HS- 1, LOC 2 & A3180 & 0 & 0 & 0 & 0 & 0 \\
\hline HS-1, LOC.3 & A3181 & 0 & 0 & 0 & 0 & 0 \\
\hline HS-1, LOC. 4 & A3182 & 0 & 0 & 0 & 0 & 0 \\
\hline LSL-II LOC. 1 & A3167 & 0 & 0 & 0 & 5 & 5 \\
\hline LSL-II LOC.2 & A3168 & $\overline{0}$ & 0 & 0 & 0 & 0 \\
\hline LSL-II LOC.3 & A3169 & 6 & 0 & 0 & 5 & 11 \\
\hline LSL-II LOC.4 & $\mathrm{A} 3170$ & 0 & 0 & 0 & 5 & 5 \\
\hline LSL-II LOC.5 & A3171 & 6 & 0 & 0 & 6 & 12 \\
\hline LSL-II LOC.6 & $\mathrm{A} 3172$ & 5 & 0 & 0 & 5 & 10 \\
\hline PSL LOC.1 & A3099 & 0 & 0 & 0 & 0 & 0 \\
\hline PSL LOC. 2 & A3100 & 0 & 0 & 0 & 0 & 0 \\
\hline PSL LOC. 3 & $\mathrm{~A} 3101$ & 0 & 0 & 0 & 0 & 0 \\
\hline PSL LOC. 4 & A3102 & $\overline{0}$ & 0 & 0 & 0 & 0 \\
\hline PSL LOC. 5 & A3103 & 0 & 0 & 0 & 0 & 0 \\
\hline RTL LOC. 1 & A3105 & 7 & 0 & 0 & 6 & 13 \\
\hline RTL LÖC.2 & A3106 & 7 & 6 & 0 & 6 & 19 \\
\hline RTL LOC. 3 & $\overline{A 3107}$ & 7 & 6 & 0 & 6 & 19 \\
\hline RTL LOC. 4 & A3108 & 0 & 0 & 0 & 0 & 0 \\
\hline RTL LOC.5 & A3109 & 0 & 0 & 0 & 0 & 0 \\
\hline RTL LOC.6 & $\overline{\mathrm{A} 3110}$ & 0 & 0 & 0 & 0 & 0 \\
\hline Sigma V, LOC.1 & A3186 & (c) & (c) & (c) & $\overline{0}$ & $\overline{0}$ \\
\hline Sigma V, LOC.2 & A3187 & (c) & (c) & (c) & 0 & 0 \\
\hline Sigma V, LOC.3 & A3188 & (c) & (c) & (c) & 0 & 0 \\
\hline Sigma V, LOC.4 & A3189 & (c) & (c) & (c) & 0 & 0 \\
\hline Sigma $\mathrm{V}$, LOC.5 & A3190 & (c) & (c) & (c) & 0 & 0 \\
\hline Sigma V, LOC. 6 & A3191 & (c) & (c) & (c) & 0 & 0 \\
\hline
\end{tabular}




\begin{tabular}{|c|c|c|c|c|c|c|}
\hline TLD Location & TLD ID\# & Deep Dose (mrem) & Deep Dose (mrem) & Deep Dose (mrem) & Deep Dose (mrem) & Deep Dose (mrem) \\
\hline 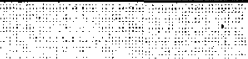 & $\cos =0$ & 1st Quarter & 2nd Quarter & 3rd Quarter & 4th Quarter & Annual \\
\hline \multicolumn{7}{|c|}{ (a) - Multiply area TLD result by 0.23 to obtain dose estimates corrected for worker occupancy. } \\
\hline \multicolumn{7}{|c|}{ (b) - Area TLD lost. } \\
\hline \multicolumn{7}{|c|}{ (c) - Sample location not initiated yet. } \\
\hline \multicolumn{7}{|c|}{ (d) - Sample location discontinued } \\
\hline \multicolumn{7}{|c|}{ (e) - Neutron dose from Hanford Standard Dosimeter } \\
\hline \multicolumn{7}{|c|}{ (f) - Neutron dose from Hanford Combination Neuton Dosimeter } \\
\hline
\end{tabular}




\section{Distribution}

No. of

Copies

OFFSITE

2 DOE/Office of Scientific and Technical Information

ONSITE

3 Babcock \& Wilcox Hanford Company
R.W. Berk
L1-02
R.L. Hill
L5-65
T.W. Milham
L1-03

2 DOE Richland Operations Office

T.L. Aldridge

K8-50

30 Pacific Northwest National Laboratory

S.G. Barrett

S.R. Bivins

P7-28

P8-17
No. of

Copies

G.D. Buckley

P7-28

V.L. Berndt

P7-01

S.D. Dossett

P7-75

P7-78

P7-28

P.J. Gaither

P7-78

P7-78

P8-55

K8-98

P7-78

P7-78

P7-57

P7-78

P7-78

K4-04

P7-02

P8-55

P7-78

P7-78 